\title{
footnotes and marginalia
}

\section{By Maren Storlien Syltevik}

\begin{abstract}
Disability or lack of health present areas of unthinkability not only to our surroundings, but to ourselves. In "footnotes and marginalia" I explore my horizon and blind spots through an analysis of James Blish's More Light, a horror story about infectious reading. Deliberately blurring the lines between genres, my text is itself infected with horror elements and becomes a horror story, twisted and outrageously wrong. As the title implies, it deals with what happens at the borders of academic inquiry, exploring embodiment and how to approach the parts of our horizons we cannot look straight at. Interested in reception on the smaller scale as well as the larger, it probes the back-and-forth between reader and text. Working with texts we all let the text into us, letting it infect us, change our inner landscapes. I include a rather detailed sensory description of such a reading process, and I hope to encourage sensory awareness in the reader as well. I hope to make you tense up and feel uneasy. I hope to make you laugh. I hope to make you flinch. In short, I hope it is as unpleasant to read as it was to write.
\end{abstract}

\section{KEYWORDS}

reception studies, disability, horror, infectious reading, unthinkability, embodiment

Maren Storlien Syltevik pursues a master's in Gender Studies at University of Oslo. Her focus is on utopian fiction, but she also regularly geeks out about science fiction, adaptation, reception, fanfiction, sexuality, disability, class, power, and horror. Some suggest she will outgrow certain research interests. She hopes they are wrong

Update: Maren was in hot pursuit of an education until time came to face the consequences of this transgression. She claims no regrets, but she cannot forget what she saw, and her horizon is changed forever. 


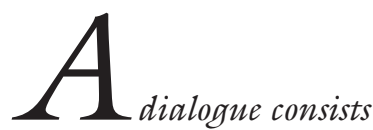

not only of two interlocutors, but also of the willingness of one to recognize and accept the other in his otherness. This is even more true when the other is represented by a text which does not speak to us immediately. (Jauss 2001, 9)

\section{CHARACTERS:}

Maren, the Reader. A student.

MAREN, the Writer

JAMES, the Reader. A science fiction writer.

JAMES, the Writer

BILL, a Messenger

Chambers, a Dead Author

LOVECRAFT, a Dead Author

CASsilda, a Queen

The Phantom of Truth

NEKRONOMIKON, a Book

IBID, a Book

The KING IN YeLLOW, a Play

HANS, a Theorist

JEANETTE, a Theorist

ROLAND, a Theorist

OMISE'EKE, a Theorist

STANLEY, a Theorist

Jo, a Theorist

JACK, a Theorist

SUSAN, a Theorist

Various writers

Various books

I know parts of this will look like I am attempting fiction, but I swear by Cassilda herself, whoever she might really be, every word is true. Please forgive me. This reading demands a different way of writing from what I'm used to. Call it genrefuck, if you're comfortable with such language - I will take no offense, it's the word I tend to use for it, and besides, I am not going to dirty up more pedestal words than I already have here. This is the language this thing demanded: Waving back and forth between the very colloquial and the more formal, and sometimes storming between them, too. This is what it is: Genrefuck. This is a true story. It is a horror story. And it is an academic - well, something. A text that takes seriously the claim that "the reader's activities are at the center of attention, where they are regarded not as leading to meaning, but as having meaning" (Fish $2002,350)$. "A stroll out of the confines of conventional knowledge and into the unregulated territories of failure, loss, and unbecoming" (Halberstam 2011, 7) - but knowledge all the same. So excuse the note of hysteria, because I really think we may need a dose of this.

I could be wrong, though. I admit it would perhaps have been better for us all if I had, for once, simply done what I was told. You would never have had to see the rest, never known what happened to me, and perhaps to Blish too; it might never have had to affect your world, and if you're good enough at compartmentalizing maybe it still won't. I hope for your sake that you are, and yet I felt compelled to show you a connection, one that could perhaps be important: 1 How infectious reading, body horror and horror of understanding are connected in James Blish's short story More Light, and beyond, or at least how they were connected for me. Different horizons, different receptions, different understandings. Which means that to do this, I need to explore a stretch of my own horizon. You see, I found my own reception of

1. This is the truth, sure, but it's also an excuse: As much as I honestly wish to save you from being infected by any level of understanding of my predicament, there is also an opposite desire: This dirty, human need to share. 
the text telling me more about the text itself, and I wanted to address that process more directly, attempting to make the reception process more transparent, or rather less opaque, than it normally is. The horror element in what I write is in part in support of that transparency objective and in part opposed to it: Every word is true, but some of the words are misleading, hinting at things I do not really believe to have the connection I imply. I have tried to confine those to the footnotes, but they have turned out to be somewhat infectious too.

I do not promise you a smooth ride. In fact, I think I can safely promise you a bumpy one, and to an unpleasant destination as well. You may find it hard to take me seriously sometimes, but "being taken seriously means missing out on the chance to be frivolous, promiscuous, and irrelevant. The desire to be taken seriously is precisely what compels people to follow the tried and true paths of knowledge production" (Halberstam 2011, 6). And I've found that getting lost is a good way to learn, so let's go get lost, shall we?

Hans Robert Jauss says that in order to meet the text's own horizon, ${ }^{2}$ we cannot simply ignore our personal one (2001, 7-8). Even so it is far too easy to trick ourselves into thinking we are that famous empty slate, that we either have some inherently neutral position or can make ourselves an intentionally blank receiver of the text. I do not believe I come from nowhere or possess some heritage of imagined neutrality, but sometimes I accidentally assume that I can make myself blank simply by intending to disregard all baggage. Or I forget it is there to begin with; consider it checked, not carry-on. But of course that is not really a thing one can do, Jauss says (ibid.), and not only should I have known that, I had known. Stanley Fish mentions "the making and revising of assumptions, the rendering and regretting of judgments" $(2002,350)$ as activities of reading and, as such, as interpretation. These activities are necessarily based on who we are and what we know. Horizon, then, is where we start. To meet the text's horizon, to "bridge the gap between otherness and speechlessness" (Jauss 2001, 9), I need to take my own horizon into account while realizing that the text is alien, other, and that all I can do is approach it.

How to approach this time, then? Let us start with a point on my horizon: On a good day I will tell you I study literature to better understand the world, with the hope of one day properly contributing to it. On a bad day, though, I will say that I study literature to better understand myself, much like the trope goes about psychology students. On a bad day, then, I am here for the personal epiphanies. I do not hunt them down, it is the other way around: I am their willing victim, part of me running, yes, always, but also insistently getting in their way by showing up and digging into the texts I find the most disturbing. In short, I am setting myself up to be bulldozed by the most unpleasant aha-moments my brain can wring out of a text. That is not to suggest that my interest in literature runs on emotional masochism,

2. Horizon pretty much means what it says on the package, but in case more is needed (and to kill off any ideas you might somehow still have about this text aiming for a professional tone), here is an explanation in the most cringe-worthy form I could think of:

There once was a scholar named Jauss

whose theory was out-of-this-house:

He said "look around, your horizon is bound to affect how you read. Now: Applaus!" 
but rather that engaging seriously with texts will frequently lead to sometimes-unpleasant changes in horizon.

I'll show you what I mean by throwing in some examples of past encounters: Pat and that other James taught me that I am a hypocrite who has repeatedly betrayed love; Jane and George drove home that I can forget about access to objective truth as it is something approachable at best; Edith and Jack reminded me that Rome didn't burn in a day either. ${ }^{3}$ Thoughts like these are what I comfort myself with on bad days. My increasing stock of them must mean I am growing, and that's good, right? Still, we all need a break sometimes, not that I got one. This is the story of what James Blish taught me.

I really don't know why I expected a class in horror literature to be something I could approach with more emotional distance than any other literature class. Perhaps it was hard for me to take the genre seriously? Much like other genres that endeavor to manipulate our bodies in some way without politely letting us pretend it does no such thing, horror has a rather low status, it's true. But more than cultural prejudice I may have felt a need to keep my teenage self at arm's length, much like the characters of More Light try to do, or like the way I still consider crime novels childish after that year I ran out of age-appropriate books in the village library and discovered Agatha Christie. And as whodunnit is my late childhood, horror is my teens. I don't know how this was supposed to pro- tect me from myself, but clearly I had the idea that it might somehow create the necessary emotional distance. Surely there is some humiliating lesson in that assumption as well, and just as surely it will hunt me down in time. It is what lessons do.

Like the body horror element of James Blish's short story More Light from 1970 did. I resisted for the longest time, but of course it got me in the end. The story fascinated me from the start, though; sinking its claws into me as if it could sense my weakness, my vulnerability to the infection of that specific horror, my chances to plant seeds of that understanding elsewhere. The first time I read it, though, I completely ignored the bodily aspect of reception. There are so many other things to notice in More Light, after all, references to things I have vaguely known and never quite understood. The story plays around with a horror cliché that was by then as passé as could be: Infectious reading. ${ }^{4}$ In the late $1800 \mathrm{~s}$ Robert W. Chambers had written several pieces of horror fiction centered around a fictional play called The King in Yellow:

\begin{abstract}
"The play set forth the nullity of all human hopes, exposed much vaunted Truth as a mere phantom, and revealed the Nihil so no one could any more deny it. Except those who dared not read the play, secretly fearing its truth (Price 2014, ix)." Such a book sets the scene for short stories where Chambers' characters read the play, which makes them mad and kills them in various ways (Chambers 2014a; 2014b).
\end{abstract}

3. It wasn't a fair fight - each book was powerful, but the novels still teamed up in pairs to give me a proper beating, which I really should feel zero stubborn pride in, but what can you do. What novels brutalized me like this? It truly doesn't matter, but since you asked: The Price of Salt (Highsmith 2004) and Giovanni's Room (Baldwin 2007). Pride and Prejudice (Austen 2001) and Nineteen Eighty-Four (Orwell 1948). The House of Mirth (Wharton 2008) and Random Acts of Senseless Violence (Womack 1993).

4. Infectious reading is a term made up by Erika Kvistad for that horror class I took, and I find it perfectly describes that type of weird fiction in which a text works on its reader in disturbing ways - most often to drive them mad. I love a good term that helps define a slippery subject. That's right, let's wrap words around it, and if the words are good enough maybe we get to believe for a little longer that we can control it. 
While the idea of accessing too much knowledge with dire consequences was hardly new, 5 Chambers was probably the first to use it as a plot device for horror. He was followed by Lovecraft, who invented the fictional book Nekronomikon, and much like Chambers used it to drive his characters mad over several of his stories as they discover that the world was populated by bigger, smarter and scarier things than humans, and that humanity is doomed. This is often known as the Cthulhu mythos. And mythos was the shape of the thing from the beginning: The early writers of this Weird Fiction, as it became known as, recycled not just their own stuff over several texts for effect, but those of various mythologies, and of course each other: The name of something terrible hinted at by Chambers found its way into Lovecraft, who borrowed words from any myth he deemed scary, ${ }^{6}$ and added terrors from earlier horror writers in much that same way (Price 2014, vii-ix).

This is what More Light sets out to play with, long after weird fiction had fallen out of fashion. The story consists of a frame story and a short play - The King in Yellow, supposedly. The play is deliberately confusing, but the frame story is apparently quite simple. It consists of two characters, apparently old friends, who argue over Chambers' infamous play over dinner. One character, Bill Atheling, claims that Chambers wrote the play and that he has it, and convinces our narrator to read it. I call the part of the story that isn't the play a frame story for clarity, 7 but this is the part of the story I will really be focusing on, because while
Blish does interesting things in the play, the frame story is where I found the horror.

Besides, there are interesting things there. For one thing, both characters appear to be Blish himself: The narrator is a writer called Jim (Blish 2014, 87, 89), and William Atheling was the pen name Blish published criticism under. There is, of course, the usual disclaimer - "Similarities between characters in this book and persons living or dead are entirely coincidental" - but it really makes more sense to disregard that as a publishing custom than assuming, as we otherwise must, that Blish had forgotten both his real name and his pen name at the time of writing. ${ }^{8}$ It seems more likely that the use is intended to blur the lines between fiction and reality, disallowing reading it fully as either. Besides, it helps make sense of the first sentence of the story as a warning of the shaky ground we're about to enter, as in this light "I have never trusted Bill Atheling" (Blish 2014, 85 ) becomes the most explicit warning of an unreliable narrator I've ever seen.

Part of the frame narrative shows Blish having a conversation with his alter ego about trying to hunt down the Nekronomikon as a teen (Blish 2014, 87). The introduction to the short story implies this really happened (Price 2014, 84), which is not much of a stretch of the imagination, at least not mine, because it happened to mirror my own hunt for the very same fictional horror tome sixty-something years later. I wasn't much interested in the horror aspect at the time, though, I was just greedy for the knowledge. As a child I used to want the elusive Ibid, ${ }^{9}$ which clearly contained

\section{The Bible springs to mind.}

6. And he found a lot of things scary, but that really is another story.

7. There should be some of that stuff around here, after all.

8. Though I bet there is an interesting and horrible reading or five in that assumption as well.

9. "Want" is not strong enough a word for what I felt. Children can feel such passionate desire for objects. I never doubted its existence or value. Why would I? It was referenced everywhere, after all, in adult books too, even. Oh, Ibid! It was among the treasures Ali Baba stole from that cave, I was sure. It was everywhere in history, rare and precious, and shone with a strange, golden light in my mind's eye. Oh, I needed that book as I had never needed anything before. Not that that helped, of course. 
most things a person needed to know about, well, everything. As a teen I saw Nekronomikon as likely to deliver some smaller but similar treasure chest of hidden knowledge. I imagine teenaged Lovecraft fanboy Blish was after the tome for the horror, mainly, although a side of knowledge would probably appeal to him as well. Teenaged me was far less diligent than he had been; unlike him I stopped short of trying to actually contact Lovecraft (Blish $2014,84)$. Granted, to do so I would have had to use different tools than Blish's pen and paper, which would have made this a very different horror story, and I promise you we're not going there. ${ }^{10}$

Blish doesn't expect the reader to believe that Atheling actually possesses and is possessed by the original infectious reading trope of his teenage fandom, The King in Yellow, and so he positions himself as a stand-in for the skeptical reader:

'Are you about to tell me you've found the play in your cellar, and that you've been haunted ever since? And then pony up a concocted manuscript to prove it? [...] You know damn well it will never sell, anyhow'. (Blish 2014, 86)

He thinks it is impossible to make a good story out of "such a stock opening" (Blish 2014,87 ) as "nobody peddles such nonsense anymore" (Blish 2014, 86). ${ }^{11}$

This move effectively anticipates the reception the story would be likely to get otherwise as it allows him to disarm the reader's more obvious reservations - not enough to convince anyone, mind you, just enough to get the narrator, and with him the reader, to suspend disbelief for long enough to read the play.
Even though Chamber describes The King in Yellow as unspeakably horrifying (Chambers 2014a; 2014b), Atheling says it is really not that bad - "I'm sure it can't hurt you a bit" (Blish 2014, 89) - it's just for some reason quite impossible to read all the way through (Blish 2014, 90). Blish agrees - no, of course he won't go mad or any such nonsense. We're all rational adults now, and we've outgrown our childish nonsense fascination with the weird, and nothing bad can come of this, it's just reading. The scene is set, and Blish can get to the act of subjecting himself to the horror of reading The King in Yellow.

Once he is alone he settles down to read, and immediately perceives the lights to dim (Blish 2014, 91), which Blish blames on Atheling's dated wiring, so of course "it was a nice coincidence and I relished it" (ibid.). The light keeps interfering throughout his reading of the play by dimming and flickering (Blish 2014, 99, 103, 104, 107, 110). His eyes are tired, the letters swim before his eyes (Blish 2014, 99). He also hears a strange rumbling and feels increasingly itchy and dirty (Blish 2014, 107, $110)$. At the end he is "so exhausted [he is] outright sick” (Blish 2014, 110).

Like I said, I didn't take much note of Blish's physical reactions during that first reading. I was too distracted by trying to figure out the deliberately confusing play itself, which I for some reason assumed was the point, and which the story presents in its entirety: Is The King in Yellow set in humanity's future or past, or some other universe? Is it the most horrifying when we take it at face value or when we don't? What is the role of time? What makes it scary - is the horror really in the blurring of the boundaries of humanity? I asked my-

10. I did at some point in this messy process enthusiastically scribble down "OMG DO YOU ACCEPT FANMAIL PER OUIJA-BOARD, SIR?” in the margin of my book, but that little note was addressed solely to Blish.

11. Which was true enough for 1970, though less true these days. 
self ultimately irrelevant questions like that, wrote them conscientiously in the margin as I read. Literature is my thing, and I do take it seriously. I am that annoying combination of sincere and pretentious that seldom fails to disturb people because they can't tell what is what, 12 so of course I was thinking about where humanity and human identity diverge in the play, not about the symptoms of my fellow reader of it. Analysis and asking the questions we think we are supposed to ask does sometimes provide a certain protection against lurking insights, especially if one's interest is genuine.

So there I was, reading, way too focused on one-upping the guy who wrote the story to do anything more than vaguely notice this admittedly rather central part of it. The margins are pristine on everything concerning Blish's own reception of the play, at least until the very end of the story. No, I wasn't much with Blish as we read together - I was trying to figure out the world of Cassilda, the hopeless queen in The King in Yellow, not that of Blish the reader. Sure, I knew the play was meant to be incomprehensible, but "meant to" is not the boundaries of a text, or if it is a boundary then it is a soft one that you can slip through without breaking if you push against it just firmly enough. Just because something looks like nonsense doesn't mean it needs to stay nonsense. They call it making sense for a reason. ${ }^{13}$

Since I wasn't with Blish as I read you may think I was with myself, a good stu- dent properly present in my own reading experience. I would have shared that assumption if it hadn't been for how re-reading it became clear that I couldn't possibly have been, not quite, because just as much as I didn't think about Blish's eye problems and his trouble with reading the play, I neglected to think of my own symptoms, so identical to his, even as we shared the activity of reading, even as we were reading the same play. Checked luggage indeed. His words blurred in front of my eyes as those of Cassilda blurred in front of his. I had squinted to make the text out as he did, I had been completely lacking of the sensible, obvious thought that perhaps it was time to stop, ${ }^{14}$ as was he. 15 The parallel was there, and I didn't notice it. All of this was present in that moment, and it passed me by - just static, just background horror. Bizarre as the thought of such utter cluelessness is, ignoring some symptoms had somehow become normal for me. I had, through grind and habit, become quite used to them.

You see, this could have been a story about the self-rejection that so frequently happens when our bodies are so far from the ideal that we become unthinkable to other people (Wendell 1996) - a story of internalized ablism as an obstruction of my view of my own horizon. 16 We need the explorations of illness and disability that deal with how society meets non-conforming bodies, but this text is not that, although that sort of thing always lurks in the background when we talk about disability. I

12. It is always both, of course.

13. Sorry, Stan (Fish 2002, and elsewhere), for butchering your theory like that - hauling it out of the water, smashing it against the stones. It deserves better, but I was hungry.

14. Oh, merciless gods, just make it stop!

15. This goes for Maren and James the writers too, I suspect. Stopping writing, or at least having the sense not to go and share the damn thing, was probably the only sensible course of action, and for me it is still an open one. Even so I struggle to even think it, and wrapping words around it is almost impossible, as if something disallows the very thought.

16. And really, who am I to say it isn't that as well? 
rather think this is about how disabilities themselves can make one's own reality unthinkable and inaccessible. Such losses may pay something back in other understandings or they may not - either way the loss of access is quite real in itself. My blurred vision means less sensory access to reality. And then there are the coping strategies. Sensory disorientation is not something I can be aware of every minute I experience it, only when I need that awareness to navigate reality, or it would swallow my world. So the blind spot here is at least partly caused by the misbehaving body itself, not the framework that categorizing it as misbehaving in the first place. I am unthinkable to other people and to myself, but it is not my lack of intelligibility to others that makes me unable to stay present in the reality of my symptoms, or if it is that too, then that is a story for another day.

Besides, navigating something old and something new are different experiences, and the symptoms have been my more or less constant companions since my teens. Of course lights inevitably do flash and dim at random or significant times - I know it's usually my sight, not my surroundings. Letters swimming, Blish? Why, that is the normal state of letters; it's what they do and how I have come to expect them to behave. Reading anything that demands more focus than children's books has frequently left me in much the state Blish describes. And of course I cannot fully trust my senses. These symptoms can be ignored, but not avoided, so I ignore them as best I can. It may go against the grain to turn my back to knowledge, but to those of us whose horizon includes a reality like this it all the same occasionally makes a certain sense to do so. Look at Blish, he is ignoring the obvious too, not only as he reads the play, but as he writes the story.

What all this comes down to is that the body horror and the knowledge horror thoroughly overlap as we flee the knowledge of our bodies. The unthinkable, the as-of-yet-deniable, is already in our bodies. If nothing else, death in the form of age will catch up - is in fact always already inescapably catching up. A lot of people certainly seem to find that prospect horrifying enough in itself, 17 even without the other losses aging tends to offer. And old age is our best-case-scenario - we are really very lucky if this horrifying thing indeed happens to us before death. If we're less lucky... well, suffice it to say that it is really no wonder disease and disability scare us, or that those in a position where it is even remotely possible to avoid thinking about it as something that could happen to them generally do, sometimes even as it is happening to them. ${ }^{18} \mathrm{We}$ may avert our eyes, deliberately looking away from understanding, or we may focus insistently at something else. ${ }^{19}$

This is one of the points where my horizon meets that of the text, although I am feeling cautious about that. "Literary understanding", Jauss warns, "becomes dialogical only when the otherness of the text is sought and recognized from the horizon of our own expectations, when no naïve fusion of horizons is considered, and when one's own expectations are corrected and extended by the experience of other" (Jauss $2001,9)$. The otherness is certainly both sought and recognized from my own horizon, run as I might, but how to tell for sure whether I have avoided considering

17. “ALL: No! Mercy! Not upon us!” (Blish 2014, 110).

18. Like I said, Rome didn't burn in a day either. Things can go to hell slowly, too slowly for us to notice for quite some time, if we are invested enough in not noticing. Don't ask me how I know.

19. Eyes on the prize, they say. If you think you can do it, you can. No pain, no gain. Never give in and never give up. Quotes like that still ring in my head, and maybe they always will. 
any naïve fusion of horizons? I have no illusions that Blish and I are talking about the same thing, but all the same I am mirroring him, aping him deliberately as well as accidentally, being his funhouse mirror as he is mine, distorting everything. Fusing? I honestly cannot tell. As for the last criteria Jauss sets for literary understanding, my expectations were certainly corrected and extended by this otherly text. That, at least, I fully trust.

Considering Jauss' warning, I certainly shouldn't try to figure out whether it makes sense to think that Blish may have written More Light to deal with some disease of his own, as a way to handle his own problems, whatever they may have been. Sure, I can speculate, briefly, let us just promise each other not to think for even a second that such speculation is the point here. As Jo Walton points out in her essay $S F$ reading protocols, the SF stories that tends to get academic acclaim are the ones that lend themselves to metaphorical readings, and while the text:

"may be literalization of metaphor, it may be open to metaphorical, symbolic and even allegorical readings, but what's real within the story is real within the story, or there's no there there". (Walton 2014, 321, my emphasis $)^{20}$

That said, let's have a peek. I've been curious too, idly wondering what Blish's intentions were. That might not be quite kosher, the author still being dead and all (Barthes 2002), ${ }^{21}$ and it might be the case that "art alters consciousness, and the consciousness of the writer in the process of writing is not the consciousness of the writer at any other time" (Winterson 1995, 57), but that doesn't mean we don't want to know about the intentions, right, or something we can feel satisfied about calling our Truth?

Are we doing this, then, for just a few paragraphs? Okay: It is certainly possible to read the text as Blish witnessing his own body, using the story to explore and exploit it, writing the horror of a body not supporting normal activities 22 into a horror story. As I know full well, all the mystical symptoms he describes are real things that can happen with real bodies, no satisfying explanation required. While disease is horrifying and we tend to look away from if we can, it can also wake up the need to look more closely, grasping for tools to handle it.

In the stories about infectious reading by Lovecraft, Chambers, and the writers who followed them, the more you learn about the mythos, the other world beyond what we see, the harder it is to hold on to reality as we know it. Insanity, then, is inevitable. Part of insanity is not being able to trust your senses. But of course there are other reasons for symptoms like that, saner reasons even, that our senses let us down. There are some indications that most of what happens to Blish and Atheling in the story is something from Blish's life, which seems to root the story in his own life - the Nekronomikon hunt (Blish 2014, 88-89), quotes from correspondence with Lovecraft (Blish 2014, 88), that kind of thing. This is a fair enough argument, I suppose, but of course it makes no sense for me to make such a suggestion, as trusting that every-

20. Which is to say, let's remember what genre we are reading and what its reading protocols are. Which is to say, let's not get too distracted by other stuff. Which is not necessarily to say other stuff isn't there.

21. Though personally I'm holding out for the Schröediger's Author theory, which is bound to show up sooner or later if it hasn't already, although probably not under that name.

22. The blurring of the letters is terrifying still, the more and less of light as it flickers even while it surely remains steady by any objective standard you can think of. 
thing must mean what it seems to is hardly a sensible argument in the context of this text I am writing. Besides, Blish also hints at a cause-and-effect connection between his reading of The King in Yellow and his symptoms, which just can't be. ${ }^{23}$ All I know is that he died a few years later, and that he didn't publish much in between. You can't prove anything, and neither can I. Besides, this is just reception studies, not a whodunnit. Proof is not the issue here, or at least not that kind of proof, the issue at hand is the process of approaching texts.

Let us look at the next step in approaching an understanding of what More Light looked like, then: Classroom discussion. This story was one of my favorite texts for this class: So unresolved and yet so insistently creepy. Blish never admits to himself or us that anything might be wrong. I loved his stubborn denial - "No mystery. Just eyestrain." (Blish 2014, 111) - but of course there is no protection in that sort of thing. It's the classic Lovecraftian mythos double bind: Knowledge cannot protect you, and neither can ignorance. ${ }^{24}$ Still, I appreciate how Blish doesn't give up on ignoring the obvious anyway. That helped make the story scary: Just because you're not paranoid in the least doesn't mean they're not after you. Just because you are as certain as you can be that nothing can be the matter doesn't make it so, and that monstrous knowledge is just under the horizon, waiting to rear its head, break the surface, look into your eyes and force you to understand. It hasn't done so yet, but the reader sees it between the lines even while the narrator does not, not even by the end of the story. Writing it down is surely part of the process that will lead him to that final understanding, though, and writing it in that tone of cocky ignorance is no protection at all. Scariest thing on the syllabus if you ask me.

I was so eager to discuss More Light that I ignored all the signs, so generously provided, that I should really stay away from class that day, only to discover that my classmates didn't sound remotely horrified. If anything, they were puzzled: Clearly there was no horror to be found in More Light. So there I was, frantically trying to shut up and not explain what I had found so very unpleasant about it, because I already knew on some level that wrapping words around my reaction to the text was the path to a flash of self-knowledge of a magnitude I would really rather not have to confront in public. I finally resorted to sitting on my hands, the weight of my body against that too-familiar drive to say what I shouldn't. I am getting better at that: Smelling the crueler flashes at some distance, run before they strike, try to get to safety. Not that there is such a thing, but all the same I run, and privacy wasn't so bad either, for as long as it lasted.

If the symptoms Blish describes as he reads the play hold anything relatable for most people, it is as something that will pass, almost by definition. Pulling a few allnighters on an urgent project may eventually produce similar effects, but while unpleasant, that is hardly horrifying, because there is no reason to doubt that it will pass. So while Atheling has chronic symptoms after reading the play (Blish 2014, 85, 112) and Blish's many broken eye-glasses (Blish 2014,112 ) implies that he does too, that may not look significant. It didn't to me those first two reads either. When this

23. Just imagine for a second if I straight-out argued for the truth of that instead of placing these small support beams of... Well, not evidence. There can be no evidence, obviously.

24. Though in Chambers (Chambers 2014a; 2014b) it seems that ignorance does offer some limited protection. Then again, we all know a reading like that is just forced optimism. No, there's no protection, in knowledge or ignorance, and in these troubled times I try to remember that. 
eventually stood out to me it was probably because sharing Blish's eye problems expanded my ability to eventually see it more clearly. Only through realizing this I began to understand this point on my own blurry horizon, could start squinting at it, hand shading my eyes. Not even the second reading had opened that possibility; only realizing the utter deviance of my experience through classroom discussion opened that door for me. I postponed the moment of understanding for as long as I could, but eventually even the unthinkable insists on being thought, and so I sat there an hour later in a sickly-yellow leather chair, shaking, wondering how my strange body could be capable of such strong convulsions with its otherwise so painfully limited strength.

I had found myself alone, my experience unshared, the landscape ${ }^{25}$ filling out that space between me and my horizon unpopulated, desolate. That, too, is horror, but of its own kind. There are parts of our horizons we cannot look straight at, stretches of horizon we have long ago stopped trying to make out. We may not even know they exist anymore. It hurts too much to look at that part, and we can't make anything out anyway, no matter how we squint, so what's the point, really? And much as we love knowledge in the abstract, when it comes to self-knowledge there is always that dance, ${ }^{26}$ aiming for some balance no matter what we believe our aims to be.

Which may be why literature is such a good tool to meet our horizon with: When we pick up a book we open up the poten- tial to be ambushed by ideas, by change; but it is just a potential, and it's impossible to know in advance which book will strike hard, and how. Even though any serious engagement with the text increases the chances, and though we may be drawn to texts that hold knowledge we need to confront, we never know for sure when such an ambush might happen, or what form it will take. And let's not fool ourselves that this only goes for well-approved literature either. Even if our intention is only to be entertained, even if we think entertainment is the only thing the book in our hand could possibly offer, even if entertainment was the only thing the writer aimed for, any book can change you, change your horizon forever. And by Cassilda, blessed and cursed, change is scary. No wonder some of us make a point never to read.

Yes, of course I know better than to blame The King in Yellow or the Nekronomikon for my problems, ${ }^{27}$ or even More Light. No, it is simply that my eyes refuse text. Even now, writing this, there is the steady thud in my brain, the flickering of the light I rationally know is steady enough for other eyes. I have closed the book, and still it works in me, on me, like The King in Yellow still worked on Blish after he left it behind (Blish 2014, 112).

My third read of More Light was the worst, for all that I now ignored the play and read only the frame story. It was after classes had ended, before the exam, the time to re-read whatever on the syllabus had fascinated me the most that semester.

25. Well, landscape, I say, as if I know what that means. "Landscape - which is not trees, rivers, or flowers, but an imaginary way of organizing these into a "whole" - in fact appears not as a preexisting entity but as a continual practice: One that (...) proves subject to constant disruption and rerouting." (Tinsley 2010, 16). Perhaps that makes our inner landscapes more like landscapes, not less. I honestly don't know.

26. Confront, avoid, avoid, confront, avoid, avoid, come on, you know the one, confront, avoid, avoid. 27. Though an excessively helpful lady told me yesterday that I would be well and able if I only hadn't read so many books and thought so many thoughts - I had assumed that idea was a hundred years dead at least, but it sure was apropos of infectious reading. I would make a Yellow Wallpaper joke here, but look, the book I have that story in weighs almost three kilos, so I'm not going to hunt for that reference. Sorrynot-sorry about that missed opportunity. 
What had been ignored on the first reads had become impossible to ignore any longer, but even as some thoughts were starting to become clearer, it was getting hard to think them properly, or to think at all, really, as if some overpowering force tried to stop me from making the connections that were so clearly there. I sat very still for a while after that re-read. I stared at my kitchen floor, which appeared to be moving up and down in soft waves, honey yellow, encouraging. I grasped at the thoughts. ${ }^{28}$ I recognised the symptoms now, mine as Blish's and his as mine. I saw how the text writes in the body, but also how my horizon was what had enabled me to open that element of More Light to the degree that the story that at first seemed to be about infectious writing really had become something more akin to body horror. Even after that third read it took weeks until this first found words, but the keyboard holds my fingers captive now as surely as the screen holds my exhausted eyes. It will not let me go until I am done. Let me be done, then:

My only defense had been not staying in the symptoms, not thinking about them, pretend they were not there. Like Blish I made believe it did not affect me much, because the alternative was unthinkable, or it should have remained so. How would it change me, I wondered, how will I endure my reality now that I know all this about it?
What effect will knowledge have when my hiding place is flushed out? I wondered, and yet I couldn't quite contemplate it. All that seemed certain was that there would be consequences for my transgression, something beyond anything I could imagine. There was no way back, though. ${ }^{29} \mathrm{I}$ cannot give back those realizations once they catch me; I never could. Perhaps all reading is infectious, or perhaps that's just me. Oh, clever, cynical James, I guess you may have been right after all. True, your cynicism and boneheaded refusal to face the facts could never save you from those facts or from their consequences, but at least you could avoid thinking the unthinkable for a while longer. I have envied you so much, you know - your stubborn refusal of knowledge, your small escape.

I have been hunted down, forced to meet understandings I cannot give back or undo. I have failed, I have lost my very identity as I have grappled the text and the text has won. The worst isn't that it gave me a beating I can still feel in my body to this day, much as I try to pretend my body is still my own. No, the worst is that my horizon is changed forever. ${ }^{30}$ I stand "corrected and extended by the experience of other" (Jauss 2001, 9), and the cost was unthinkable until it was impossible to ignore. Perhaps I have passed on some understanding to you, and perhaps not. Either way, please forgive me.

28. You know, like that machine at amusement parks where you steer a claw towards the little toy you have your heart set on. That clawed thing that pretends it wants to help you pick up a teddy, while what it really does it eat your money and, though this may take a few tries over the years, your hope. Don't go near the thing with claws over there, child! But no parental warning can stand against a child's hope and its urge to put itself in the path of destruction, much like no banning of The King in Yellow can stand against humanity's hope and its tendencies to the same.

29. This paragraph used to be written in the present tense in the first draft. I didn't know. I tried to write as if I had some idea, but of course I couldn't. Now that I do, I regret the loss of even that innocence. 30. "The King (offstage, remote, diminishing): What?!

Did you think to be human still?” (Blish 2014, 110) 


\section{REFERENCES}

- Austen, J. 2001. Pride and Prejudice: A Norton Critical Edition. New York: W. W. Norton and Company, Inc.

- Baldwin, J. 2007. Giovanni's Room. London: Penguin.

- Barthes, R. 2002. Ch. 14: The Death of the Author. In: Finkelstein, D. and Cleery, A. (eds.). The Book History Reader. New York: Routledge, 221224.

- Blish, J. 2014. More Light. In: Price, R M. (ed.) The Hastur Cycle: Second Revised Edition. Chaosium.inc, 85-112.

. Chambers, R.W. 2014a. The Repairer of Reputations. In: Price, R.M. (ed.). The Hastur Cycle: Second Revised Edition. Chaosium.inc, 11-37.

- Chambers, R.W. 2014b. The Yellow Sign. In: Price, R.M. (ed.). The Hastur Cycle: Second Revised Edition. Chaosium.inc, 39-53.

- Fish, S. 2002. Ch. 27: Interpreting the Variorum. In: Finkelstein, D. and Cleery, A. (eds.). The Book History Reader. New York: Routledge, 22 1-224.

. Halberstam, J. 2011. The Queer Art of Failure.

Durham: Duke University Press.

- Highsmith, P. 2004. The Price of Salt. New York: W. W. Norton \& Company, Inc.

· Jauss, H.R. 2001. The Identity of the Poetic Text in the Changing Horizon of Understanding. In: Machor, J.L. and Goldstein, P. (eds.). Reception Study: From Literary Theory to Cultural Studies. New York: Routledge, 7-28.

. Orwell, G. 1948. Nineteen Eighty-Four. Mobi edition, Signet Classic.

- Price, R.M. 2014. Preface to More Light. In: Price, R.M. The Hastur Cycle: Second Revised Edition. Chaosium.inc, 84.

- Tinsley, O.N. 2010. Introduction: The Spring of Her Look. In: Tinsley, O. N. Thiefing Sugar: Eroticism Between Women in Caribbean Literature. Durham: Duke University Press, 1-28.

- Walton, J. 2014. SF reading protocols. In: · Walton, J. What Makes This Book So Great. New York: Tor, 319-323.

.Wendell, S. 1996. Ch. 4: The Flight from the Rejected Body. In: Wendell, S. The Rejected Body. Feminist Philosophical Reflections on Disability. New York: Routledge, 85-116.

-Wharton, E. 2008. The House of Mirth. Oxford: Oxford University Press.

- Winterson, J. 1995. Testimony Against Gertrude Stein. In: Winterson, J. Art Objects: Essays on Ecstasy and Effrontery. London: Vintage, 45-60. - Womack, J. 1993. Random Acts of Senseless Violence. London: The Orion Publishing Group. 